\title{
Rhodovulum bhavnagarense sp. nov., a phototrophic alphaproteobacterium isolated from a pink pond
}

\author{
A. Srinivas, ${ }^{1}$ K. Rahul, ${ }^{1}$ E. V. V. Ramaprasad, ${ }^{1}$ Ch. Sasikala ${ }^{1}$ \\ and Ch. V. Ramana ${ }^{2}$ \\ ${ }^{1}$ Bacterial Discovery Laboratory, Centre for Environment, Institute of Science and Technology, \\ J. N. T. University, Kukatpally, Hyderabad 500 085, India \\ ${ }^{2}$ Department of Plant Sciences, School of Life Sciences, University of Hyderabad, \\ PO Central University, Hyderabad 500 046, India
}

Ch. Sasikala sasi449@yahoo.ie or r449@sify.com

Purple, brown and pink ponds are commonly observed in the marine and freshwater habitats of India. Two new marine phototrophic species (Rhodovulum lacipunicei, Kalyan Chakravarthy et al., 2009; Rhodovulum phaeolacus, Lakshmi et al., 2011) and a freshwater phototroph (Rhodobacter ovatus, Srinivas et al., 2008) were previously reported from such ponds. In the present study, we report a novel species of the genus Rhodovulum which was isolated from a pink pond in Gujarat, India. Members of the genus Rhodovulum are representatives of isolates from marine habitats and, at the time of writing, there were 13 species with validly published names assigned to this genus (Lakshmi et al., 2011).

Strain JA738 ${ }^{\mathrm{T}}$ was isolated from a sediment sample of a pink pond near Nari solar salterns at Bhavnagar in Gujarat, India (GPS position: $21^{\circ} 78^{\prime} \mathrm{N} 72^{\circ} 08^{\prime} \mathrm{E}$ ). The sample that yielded strain $\mathrm{JA} 38^{\mathrm{T}}$ had a $\mathrm{pH}$ of 7 and salinity of $2 \%$

The GenBank/EMBL/DDBJ accession number for the 16S rRNA gene sequence of strain $\mathrm{JA} 738^{\top}$ is FR828479.

Four supplementary figures are available with the online version of this paper. (w/v), and was collected on 12 May 2011. The culture was originally enriched in medium for photoheterotrophic bacteria in $50 \mathrm{ml}$ fully filled screw-capped bottles incubated at $2400 \mathrm{~lx}$ fluorescent light, $28-30{ }^{\circ} \mathrm{C}$ for 7 days. The medium described by Lakshmi et al. (2009) was used for enrichment and growth of strain $\mathrm{JA} 738^{\mathrm{T}}$. Sodium acetate $(0.1 \% \mathrm{w} / \mathrm{v})$, sodium succinate $(0.1 \% \mathrm{w} / \mathrm{v})$ and sodium pyruvate $(0.1 \% \mathrm{w} / \mathrm{v})$ were used as carbon sources, yeast extract $(0.03 \% \mathrm{w} / \mathrm{v})$ was used as a vitamin source and ammonium chloride $(0.06 \% \mathrm{w} / \mathrm{v})$ was used as a nitrogen source. $\mathrm{Na}_{2} \mathrm{~S} .9 \mathrm{H}_{2} \mathrm{O}(2 \mathrm{mM}$; neutralized under a stream of argon gas) was added to the medium after autoclaving, which was done in an argon atmosphere. Phototrophic incubation of the sample at $2400 \mathrm{~lx}$ and $28-30{ }^{\circ} \mathrm{C}$ for 4-5 days resulted in the formation of reddish brown enrichment. Purification was performed by repeated streaking on agar slants $(25 \times 150 \mathrm{~mm}$ test tubes sealed with butyl rubber corks). Purified cultures were grown in completely filled screw cap test tubes $(10 \times 100 \mathrm{~mm})$ for photoheterotrophic growth. Comparative taxonomic analysis of strain JA738 ${ }^{\mathrm{T}}$ with the type strain of Rhodovulum adriaticum Imhoff $6 \mathrm{II}^{\mathrm{T}}\left(=\mathrm{DSM} 2781^{\mathrm{T}}\right)$ was performed in the authors' laboratory. 
Genomic DNA was extracted and purified according to the method of Marmur (1961), and the G+C content of the DNA, determined by reverse-phase HPLC (Mesbah et al., 1989), was $63.4 \mathrm{~mol} \%$. Cell material for 16S rRNA gene sequencing was taken from a colony. DNA was extracted and purified by using a genomic DNA extraction kit (Qiagen). Recombinant Taq polymerase (Genei) was used for PCR. The complete length of the 16S rRNA gene sequence was obtained by amplification with four primers, $\mathrm{F}^{\prime}$-27 (5'-GTTTGATCCTGGCTCAG-3'), F'-372 (5' TACGGGAGGCAGCAG-3'), F'-790 (5'-GGTTACCTTGTTACGACT-3') and R'-1489 (5'-TACCTTGTTACGACTTCA$3^{\prime}$ ) [Positions 11-27 and 1489-1506 for $\mathrm{F}^{\prime}-27$ and $\mathrm{R}^{\prime}-1489$ respectively, according to the Escherichia coli 16S rRNA numbering system of the International Union of Biochemistry (Brosius et al., 1978; Lane et al., 1985)]. PCR amplification was performed as described previously (Imhoff \& Pfennig, 2001; Imhoff et al., 1998) and 16S rRNA gene sequences were obtained (without gene cloning) by cycle sequencing with a SequiTherm sequencing kit (Biozym) and chain termination reaction using an automated laser fluorescence sequencer (Pharmacia). The identification of phylogenetic neighbours and calculation of pairwise 16S rRNA gene sequence similarity were achieved using the NCBI-BLAST search (Altschul et al., 1990) and EzTaxon server (Chun et al., 2007). The CLUSTAL $\mathrm{W}$ algorithm of MEGA 4 software was used for sequence alignments and MEGA 4 software (Tamura et al., 2007) was also used for phylogenetic analysis of the individual sequences. Distances were calculated by using the Kimura correction in a pairwise deletion manner (Tamura et al., 2007). Neighbour-joining (NJ) and minimum evolution (ME) methods in the MEGA 4 software were used to construct phylogenetic trees. Percentage support values were obtained using a bootstrap procedure. These phylogenetic data showed that the novel isolate branched separately but clustered with type strains of species of the genus Rhodovulum in the class Alphaproteobacteria. The highest sequence similarities for strain $\mathrm{JA} 738^{\mathrm{T}}$ were found with the type strains of Rhodovulum adriaticum DSM $2781^{\mathrm{T}}$ (96.4\% 16S rRNA gene sequence similarity) and other members of the genus Rhodovulum ( $<96.1 \%$; Fig. 1; ME tree is shown as Fig. S1, available in IJSEM online).

Morphological properties (cell shape, cell division, cell size, flagella) were examined under a phase-contrast light microscope (BH-2; Olympus). Cells of strain $\mathrm{JA} 738^{\mathrm{T}}$ were oval to rod-shaped, $1-1.8 \mu \mathrm{m}$ long and $0.5-0.9 \mu \mathrm{m}$ wide, non-motile and multiplied by binary fission. The internal membrane structures were viewed with a transmission electron microscope (H-7500; Hitachi), after the cells had been processed as described by Hanada et al. (2002) and strain $\mathrm{JA} 738^{\mathrm{T}}$ was observed to have a vesicular type of internal membrane structures (Fig. S2).

The colour of the photosynthetically grown cell suspension was reddish brown. In vivo absorption spectra as measured in sucrose solution (Trüper \& Pfennig, 1981) with a Spectronic Genesys 2 spectrophotometer, exhibited maxima at
380, 479, 590, 803 and $863 \mathrm{~nm}$ (Fig. S3) indicating the presence of bacteriochlorophyll $a$. The absorption spectrum for pigments extracted with acetone gave maxima at $303,309,348,456$ and $486 \mathrm{~nm}$ indicating the presence of carotenoids of the spheroidene series (Britton et al., 2004). Carotenoid content was determined by $\mathrm{C}_{18}$-HPLC analysis, (eluted with acetonitrile/methanol/ethylacetate, $5: 4: 1$ by vol.; flow rate, $1 \mathrm{ml} \mathrm{mt}^{-1}$; absorption at $450 \mathrm{~nm}$ ) with a Photo Diode Array (PDA) detector. Strain $\mathrm{JA} 738^{\mathrm{T}}$ had a carotenoid content $(\mathrm{mol} \%)$ of spheroidene $(16 \%)$, demethylspheroidene $(16 \%)$, spheroidenone $(48 \%), \mathrm{OH}$-spheroidene $(17 \%)$ and neurosporene $(3 \%)$.

Growth was measured turbidometrically at $660 \mathrm{~nm} . \mathrm{NaCl}$ improved growth yields of strain $\mathrm{JA} 738^{\mathrm{T}}$ [salinity range and optimum were $1-7 \%$ and $1-3 \%(\mathrm{w} / \mathrm{v}) \mathrm{NaCl}$, respectively]. Strain $\mathrm{JA} 738^{\mathrm{T}}$ grew over a $\mathrm{pH}$ range of 7.0-9.5 (optimum, 7.0-8.0) and at $25-35{ }^{\circ} \mathrm{C}$ (optimum, $28{ }^{\circ} \mathrm{C}$ ). Strain JA738 ${ }^{\mathrm{T}}$ had an obligate requirement for sulfide as electron donor and photo- (anaerobic light; $2400 \mathrm{~lx}$ ) or chemo- (aerobic dark) lithoheterotrophy [with $\mathrm{Na}_{2} \mathrm{~S} .9 \mathrm{H}_{2} \mathrm{O}(1 \mathrm{mM})$ or $\mathrm{Na}_{2} \mathrm{~S}_{2} \mathrm{O}_{3}$ $(2 \mathrm{mM})$ as electron donor and pyruvate $(0.03 \% \mathrm{w} / \mathrm{v})$ as carbon source] is the preferred growth mode. Chemoorganoheterotrophy [dark aerobic with pyruvate $(0.3 \%, \mathrm{w} / \mathrm{v})$ as electron and carbon source], photolithoautotrophy [anaerobic light $(2400 \mathrm{~lx})$, with $\mathrm{Na}_{2} \mathrm{~S}(2 \mathrm{mM}) / \mathrm{Na}_{2} \mathrm{~S}_{2} \mathrm{O}_{3}(2 \mathrm{mM}) / \mathrm{H}_{2}$ $(20 \%, \mathrm{v} / \mathrm{v})$ as electron donors and $\mathrm{NaHCO}_{3}(0.1 \%, \mathrm{w} / \mathrm{v})$ as carbon source], chemolithoautotrophy [dark aerobic with $\mathrm{Na}_{2} \mathrm{~S}_{2} \mathrm{O}_{3} \cdot 5 \mathrm{H}_{2} \mathrm{O}(1 \mathrm{mM})$ as electron donor and $\mathrm{NaHCO}_{3}$ $(0.1 \%, \mathrm{w} / \mathrm{v})$ as carbon source] and fermentative growth [dark anaerobic with pyruvate/glucose $(0.3 \%, \mathrm{w} / \mathrm{v})$ as fermentable substrates] could not be demonstrated. Vitamin requirement was tested by replacing yeast extract with single or combinations of vitamins as growth factors; strain $\mathrm{JA} 738^{\mathrm{T}}$ required thiamine and pantothenate as growth factors.

Carbon source utilization was tested using propionate, butyrate, caproate, valerate, lactate, glycerol, and ethanol at a concentration of $0.1 \%(\mathrm{v} / \mathrm{v})$; other compounds tested were used at $0.3 \%(\mathrm{w} / \mathrm{v})$, with $\mathrm{NaHCO}_{3}(0.1 \%)$, and their utilization under photolithoheterotrophic conditions by strain $\mathrm{JA}_{73} 8^{\mathrm{T}}$ is shown in Table 1 . For testing sulfur sources, $\mathrm{MgSO}_{4} \cdot 7 \mathrm{H}_{2} \mathrm{O}$ was replaced by $\mathrm{MgCl}_{2} \cdot 5 \mathrm{H}_{2} \mathrm{O}(0.2 \%)$, and respective sulfur sources (sodium sulfide, sodium thiosulfate, sodium thioglycolate, cysteine, magnesium sulfate, sodium sulfite; all at $0.5 \mathrm{mM}$ concentration) were added to the medium. Sulfide, thiosulfate or cysteine are obligatory and were used as sulfur sources, while sulfate, sulfite, thiogylcolate and methionine did not support phototrophic growth of strain $\mathrm{JA} 738^{\mathrm{T}}$. Nitrogen source utilization was tested by replacing ammonium chloride with different nitrogen sources at $0.06 \%(\mathrm{w} / \mathrm{v})$. Strain JA738 ${ }^{\mathrm{T}}$ could utilize ammonium chloride, glutamate and glutamine as nitrogen sources, but nitrate, nitrite, aspartate, asparagine and dinitrogen did not support growth.

For analysis of cellular fatty acids, photolithoheterotrophically grown cultures in the presence of $\mathrm{Na}_{2} \mathrm{~S} .9 \mathrm{H}_{2} \mathrm{O}$ $(1 \mathrm{mM})$ were harvested when growth of the cultures was 


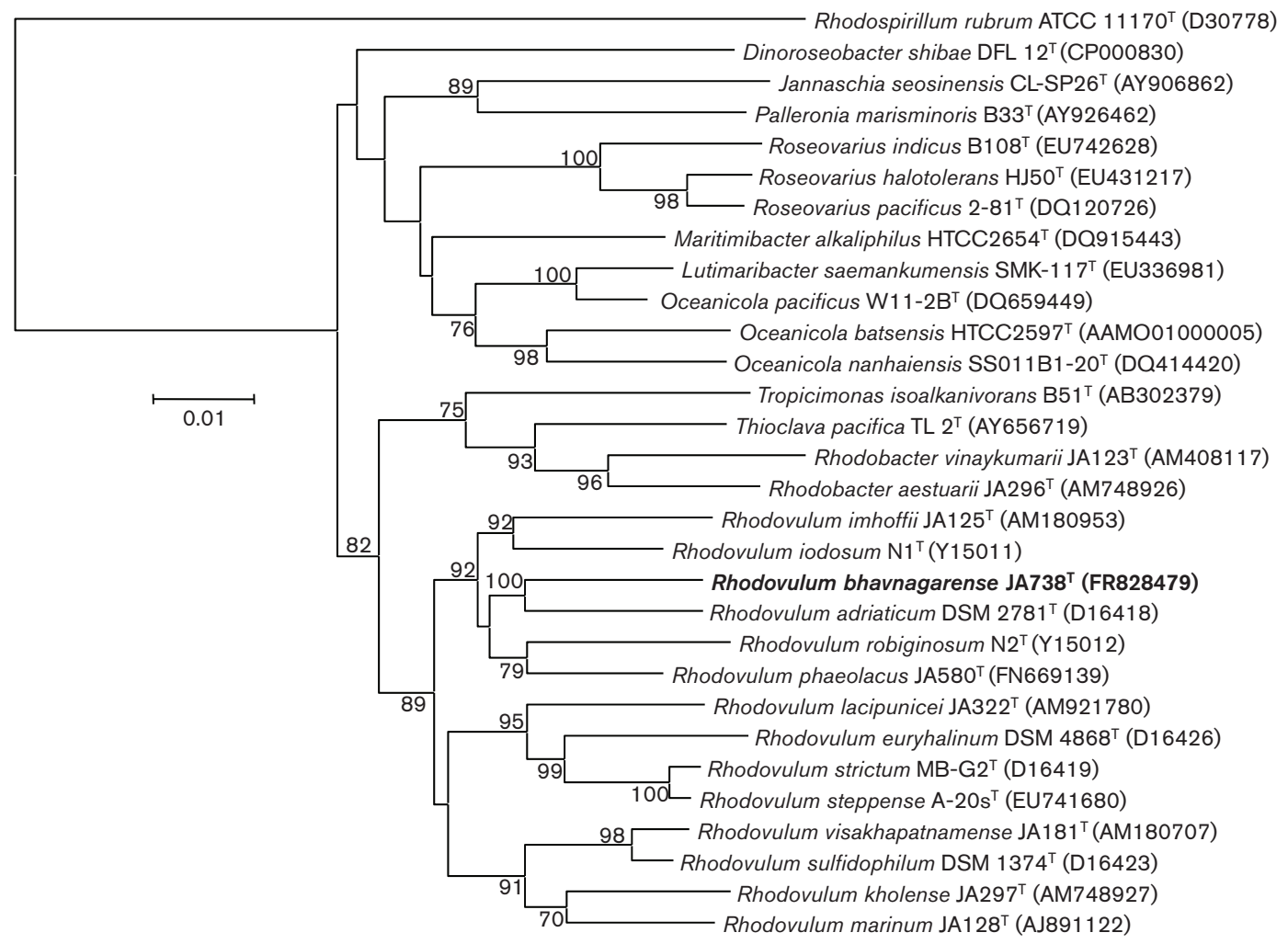

Fig. 1. Phylogenetic tree based on almost-complete $16 \mathrm{~S}$ rRNA gene sequences showing the relationship of strain $J A 738^{\top}$ within the class Alphaproteobacteria. The trees were constructed by the neighbour-joining method using MEGA 4 software and rooted by using Rhodospirillum rubrum ATCC $11170^{\top}$ as the outgroup. Numbers at nodes represent bootstrap values (based on 100 resamplings). The GenBank accession numbers for 16S rRNA gene sequences are shown in parentheses. Bar, 1 nt substitution per 100 nt.

around $70 \%$ of its maximal optical density. Cellular fatty acids were methylated, separated and identified according to the instructions for the Microbial Identification System (Sasser, 1990) (Microbial ID; MIDI; version 3V 6.0-2007; RTSBA6 database; 6850 series II gas chromatograph, Agilent) which was outsourced through Royal Research Laboratories, Secunderabad, India. The major fatty acids of strain $\mathrm{JA}_{738^{\mathrm{T}}}$ were $\mathrm{C}_{18: 1} \omega 7 c, \mathrm{C}_{18: 0}, \mathrm{C}_{18: 1} \omega 5 c$, and $\mathrm{C}_{18: 1} \omega 7 c$ 11-methyl, while $\mathrm{C}_{16: 0}$ and $\mathrm{C}_{10: 0} 3-\mathrm{OH}$ are present in minor amounts (Table 1).

Polar lipids were extracted from $1 \mathrm{~g}$ freeze-dried cells with methanol/chloroform/saline $(2: 1: 0.8$, by vol.) as described by Kates (1986). Lipids were separated using silica gel TLC (Kieselgel $60 \mathrm{~F}_{254}$; Merck) by two-dimensional chromatography using chloroform-methanol-water $(75: 32: 4$, by vol.) in the first dimension and chloroform-methanol-acetic acid-water $(86: 16: 15: 4$, by vol.) in the second dimension (modified after Tindall, 1990a, b; Oren et al., 1996). The total lipid profile was visualized by spraying with $5 \%$ ethanolic molybdophosphoric acid and further characterized by spraying with ninhydrin (for amino groups), molybdenum blue (for phosphates), Dragendorff's reagent (for quaternary nitrogen) or $\alpha$-naphthol (for sugars) (Kates, 1972; Oren et al., 1996) and cresyl violet (for sulfolipids; Soto et al.,
2000). Strain $J A 738^{\mathrm{T}}$ contained phosphatidylglycerol (PG), phosphatidylethanolamine (PE), two unidentified sulfolipids (SL1-2) and an unidentified polar lipid (L1; Table 1; Fig. S4). Strain $J A 738^{\mathrm{T}}$ differed from its phylogenetically closest relative $R$. adriaticum Imhoff $6 \mathrm{II}^{\mathrm{T}}$ by the absence of unidentified polar lipid L2 and an unidentified phospholipid (PL). The presence of various sulfolipids in strain $\mathrm{JA} 738^{\mathrm{T}}$ is in line with the genus description of Rhodovulum (Hiraishi \& Ueda, 1994). Quinones were extracted with a chloroformmethanol $(2: 1, \mathrm{v} / \mathrm{v})$ mixture, purified by TLC and analysed by HPLC (Hiraishi \& Hoshino, 1984; Hiraishi et al., 1984). Strain $\mathrm{JA} 738^{\mathrm{T}}$ contained Q-10 as the major quinone

The 16S rRNA gene sequence similarity $(<96.4 \%)$ with members of the genus Rhodovulum allows strain $\mathrm{JA} 738^{\mathrm{T}}$ to be described as a novel species (Tindall et al., 2010). Strain $\mathrm{JA} 738^{\mathrm{T}}$ is also distinct from all other members of the genus Rhodovulum (Lakshmi et al., 2011) in its obligate requirement for pantothenate in addition to thiamine for growth. Further, the genotypic difference of strain $\mathrm{JA} 738^{\mathrm{T}}$ is also supported by phenotypic differences with its closest relative, Rhodovulum adriaticum Imhoff $6 \mathrm{II}^{\mathrm{T}}$. Major differences between the two are observed in $\mathrm{NaCl}$ tolerance, chemotrophic growth, colour of cell suspension, vitamin and organic substrate requirements, carotenoid and fatty acid 


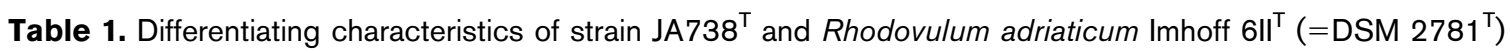

All data from this study. For both taxa, organic substrate utilization was tested during photolithotrophic growth. Both taxa were non-motile and utilized pyruvate and succinate, but not benzoate and fructose. +, Substrate utilized or present; - substrate not utilized or absent. PG, phosphatidylglycerol; PE, phosphatidylethanolamine; SL1-2, unidentified sulfolipids; PL, unidentified phospholipid; L1-2, unidentified lipids.

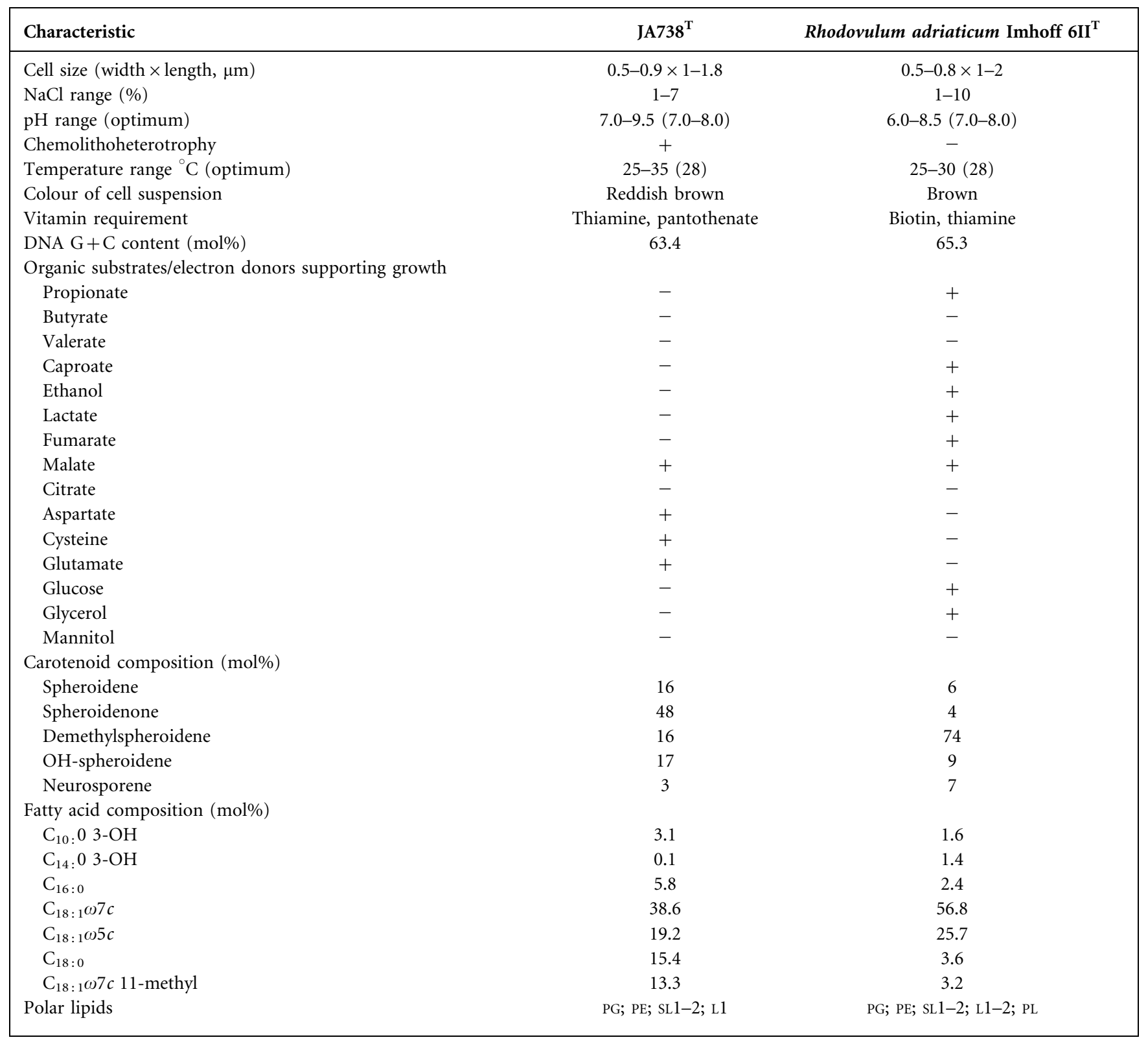

composition (Table 1) and polar lipid composition (Fig. S4). Taken together these data justify the description of strain $\mathrm{JA} 738^{\mathrm{T}}$ as representative of a novel species in the genus Rhodovulum, for which the name Rhodovulum bhavnagarense sp. nov. is proposed.

\section{Description of Rhodovulum bhavnagarense sp. nov.}

Rhodovulum bhavnagarense (bhav.na.gar.en'se. N.L. neut. adj. bhavnagarense of or belonging to Bhavnagar, a coastal place in Gujarat, India famous for solar salterns).
Cells are oval to rod-shaped, $1.0-1.8 \mu \mathrm{m}$ long and $0.5-$ $0.9 \mu \mathrm{m}$ wide, non-motile and divide by binary fission. Growth occurs under anaerobic conditions in the light. Internal photosynthetic membranes are of vesicular type. The colour of phototrophic cultures is reddish brown. Photosynthetic pigments are bacteriochlorophyll $a$ and carotenoids of the spheroidene series. Optimum growth occurs at $28{ }^{\circ} \mathrm{C}$ (range, $25-35^{\circ} \mathrm{C}$ ), and pH 7.0-8.0 (range, $\mathrm{pH} 7.0-9.5)$. Optimal growth occurs at $1-3 \% \mathrm{NaCl}$ and can tolerate $\mathrm{NaCl}$ up to $7 \%$. Photo- or chemolithoheterotrophy with $\mathrm{Na}_{2} \mathrm{~S} .9 \mathrm{H}_{2} \mathrm{O}$ as electron donor and a few organic compounds as carbon sources are the 
growth modes. Carbon sources which support growth are malate, aspartate, cysteine, pyruvate, succinate and glutamate. Does not utilize fumarate, propionate, butyrate, valerate, caproate, ethanol, lactate, citrate, glucose, fructose, glycerol, mannitol or benzoate as carbon sources. Utilizes ammonium chloride, glutamate and glutamine as nitrogen sources, but not nitrate, nitrite, aspartate, asparagine or dinitrogen. Obligate requirement of sulfide or thiosulfate as $\mathrm{e}^{-}$/sulfur source. Thiamine and pantothenate are required as growth factors. Predominant cellular fatty acids are $\mathrm{C}_{18: 1} \omega 7 c, \mathrm{C}_{18: 0,}, \mathrm{C}_{18: 1} \omega 5 c$ and $\mathrm{C}_{18: 1} \omega 7 c 11$ methyl with minor amounts of $\mathrm{C}_{10: 0} 3-\mathrm{OH}$ and $\mathrm{C}_{16: 0}$ also present. Q-10 is the major quinone. Major polar lipids are phosphatidylglycerol, phosphatidylethanolamine, unidentified sulfolipids (SL1-2) and a polar lipid (L1).

The type strain, JA738 ${ }^{\mathrm{T}}\left(=\mathrm{DSM} 24766^{\mathrm{T}}=\mathrm{KCTC} 15110^{\mathrm{T}}\right)$ was isolated from a sediment sample of a pink pond, near Bhavnagar, Gujarat, India. The DNA G $+\mathrm{C}$ content of the type strain is $63.4 \mathrm{~mol} \%$ (by HPLC).

\section{Acknowledgements}

Financial assistance received from MoES, Government of India is acknowledged. E. V.V.R. acknowledges the CSIR, Government of India, for the award of SR fellowship. We thank Professor J. Euzéby for his expert suggestion concerning the correct genus name, species epithet and Latin etymology.

\section{References}

Altschul, S. F., Gish, W., Miller, W., Myers, E. W. \& Lipman, D. J. (1990). Basic local alignment search tool. J Mol Biol 215, 403-410.

Britton, G., Liaaen-Jensen, S. \& Pfander, H. (2004). Carotenoids with a C40 skeleton. (a) hydrocarbons. In Carotenoids Handbook, Main List 31, pp. 1-50. Edited by G. Britton, S. Liaaen-Jensen \& H. Pfander. Boston: Birkhauser.

Brosius, J., Palmer, M. L., Kennedy, P. J. \& Noller, H. F. (1978). Complete nucleotide sequence of a $16 \mathrm{~S}$ ribosomal RNA gene from Escherichia coli. Proc Natl Acad Sci U S A 75, 4801-4805.

Chun, J., Lee, J.-H., Jung, Y., Kim, M., Kim, S., Kim, B. K. \& Lim, Y. W. (2007). EzTaxon: a web-based tool for the identification of prokaryotes based on $16 \mathrm{~S}$ ribosomal RNA gene sequences. Int J Syst Evol Microbiol 57, 2259-2261.

Hanada, S., Takaichi, S., Matsuura, K. \& Nakamura, K. (2002). Roseiflexus castenholzii gen. nov., sp. nov., a thermophilic, filamentous, photosynthetic bacterium that lacks chlorosomes. Int J Syst Evol Microbiol 52, 187-193.

Hiraishi, A. \& Hoshino, Y. (1984). Distribution of rhodoquinone in Rhodospirillaceae and its taxonomic implications. J Gen Appl Microbiol 30, 435-448.

Hiraishi, A. \& Ueda, Y. (1994). Intragenic structure of the gunus Rhodobacter: Transfer of Rhodobacter sulfidophilus and related marine species to the genus Rhodovulum gen. nov. Int J Syst Bact 44, 15-23.

Hiraishi, A., Hoshino, Y. \& Kitamura, H. (1984). Isoprenoid quinone composition in the classification of Rhodospirillaceae. J Gen Appl Microbiol 30, 197-210.
Imhoff, J. F. \& Pfennig, N. (2001). Thioflavicoccus mobilis gen. nov., sp. nov., a novel purple sulfur bacterium with bacteriochlorophyll $b$. Int $J$ Syst Evol Microbiol 51, 105-110.

Imhoff, J. F., Süling, J. \& Petri, R. (1998). Phylogenetic relationships among the Chromatiaceae, their taxonomic reclassification and description of the new genera Allochromatium, Halochromatium, Isochromatium, Marichromatium, Thiococcus, Thiohalocapsa and Thermochromatium. Int J Syst Bacteriol 48, 1129-1143.

Kalyan Chakravarthy, S., Sucharitha, K., Sasikala, Ch. \& Ramana, Ch. V. (2009). Rhodovulum lacipunicei sp. nov., an obligate sulfidedemanding phototrophic alphaproteobacterium isolated from a purple pond in India. Int J Syst Evol Microbiol 59, 1615-1619.

Kates, M. (1972). Techniques of Lipidology. New York: Elsevier.

Kates, M. (1986). Techniques of Lipidology: Isolation, Analysis, and Identification of Lipids. Amsterdam: Elsevier.

Lakshmi, K. V. N. S., Sasikala, Ch. \& Ramana, Ch. V. (2009). Rhodoplanes pokkaliisoli sp. nov., a phototrophic alphaproteobacterium isolated from a waterlogged brackish paddy soil. Int J Syst Evol Microbiol 59, 2153-2157.

Lakshmi, K. V. N. S., Sasikala, Ch., Ramana, V. V., Ramaprasad, E. V. \& Ramana, C. V. (2011). Rhodovulum phaeolacus sp. nov. a phototrophic alphaproteobacterium isolated from a brown pond. J Gen Appl Microbiol 57, 145-151.

Lane, D. J., Pace, B., Olsen, G. J., Stahl, D. A., Sogin, M. L. \& Pace, N. R. (1985). Rapid determination of $16 \mathrm{~S}$ ribosomal RNA sequences for phylogenetic analyses. Proc Natl Acad Sci U S A 82, 6955-6959.

Marmur, J. (1961). A procedure for the isolation of deoxyribonucleic acid from micro-organisms. J Mol Biol 3, 208-218.

Mesbah, M., Premachandran, U. \& Whitman, W. B. (1989). Precise measurement of the $\mathrm{G}+\mathrm{C}$ content of deoxyribonucleic acid by highperformance liquid chromatography. Int J Syst Bacteriol 39, 159-167.

Oren, A., Duker, S. \& Ritter, S. (1996). The polar lipid composition of Walsby's square bacterium. FEMS Microbiol Lett 138, 135-140.

Sasser, M. (1990). Identification of bacteria by gas chromatography of cellular fatty acids, MIDI Technical Note 101. Newark, DE: MIDI Inc.

Soto, C. Y., Cama, M., Gibert, I. \& Luquin, M. (2000). Application of an easy and reliable method for sulfolipid-I detection in the study of its distribution in Mycobacterium tuberculosis strains. FEMS Microbiol Lett 187, 103-107.

Srinivas, T. N. R., Anil Kumar, P., Sasikala, Ch., Spröer, C. \& Ramana, ChV. (2008). Rhodobacter ovatus sp. nov., a phototrophic alphaproteobacterium isolated from a polluted pond. Int J Syst Evol Microbiol 58, 1379-1383.

Tamura, K., Dudley, J., Nei, M. \& Kumar, S. (2007). MEGA4: molecular evolutionary genetics analysis (MEGA) software version 4.0. Mol Biol Evol 24, 1596-1599.

Tindall, B. J. (1990a). Lipid composition of Halobacterium lacusprofundi. FEMS Microbiol Lett 66, 199-202.

Tindall, B. J. (1990b). A comparative study of the lipid composition of Halobacterium saccharovorum from various sources. Syst Appl Microbiol 13, 128-130.

Tindall, B. J., Rosselló-Móra, R., Busse, H.-J., Ludwig, W. \& Kämpfer, P. (2010). Notes on the characterization of prokaryote strains for taxonomic purposes. Int J Syst Evol Microbiol 60, 249-266.

Trüper, H. G. \& Pfennig, N. (1981). Isolation of members of the families Chromatiaceae and Chlorobiaceae. In The Prokaryotes: a Handbook on Habitats, Isolation, and Identification of Bacteria, pp. 279-289. Edited by M. P. Starr, H. Stolp, H. G. Trüper, A. Balows \& H. G. Schlegel. Berlin: Springer. 